\title{
THE MILK YIELD OF UKRAINIAN HOLSTEIN IS RELATED TO THE IMMUNOBIOLOGICAL PARAMETERS OF BLOOD OF CALVES
}

\author{
Dnepropetrovsk State University of Agriculture and Economics, Dnipro, Ukraine \\ ${ }^{1}$ National University of Life and Environmental Sciences of Ukraine, Kyiv, Ukraine \\ ${ }^{2}$ Department of Ruminant Science, West Pomeranian University of Technology, Szczecin, Poland
}

\begin{abstract}
Decrease in productive longevity of dairy cows in conditions of industrial dairy complexes causes another problem, which is connected with the timely replenishment of the herd with calves for replacement. Therefore, the cultivation of heifers has very great impact. Much attention is focused on early prediction of the future calves productivity for obtaining highly productive cows. At the same time, the growth rates and development in ontogenesis are studied very often, but blood values are rarely evaluated. In the literature available to us, there is little information about the relationship between calves' humoral and cellular immunity values with the future productivity of the cow. These indicators are traditionally used to characterize the immunobiological reactivity of an organism and the calves' health, and there is practically no information on their relationship to the productive longevity of a dairy cow. This is partly due to the difficulties associated with the duration of the research, since the cow must complete its productive life. A positive and reliable relationship is established between the immunobiological characteristics of calves' blood and their lifelong milk yield when they become a cow. The greatest correlation was noted between the milk productivity's indicators and bactericidal activity of blood serum $(r=0.63-0.69, P<0.05)$. The relationship between cellular factors of body defense (phagocytic activity of neutrophils) and the immunoglobulins content of classes $G$ and $M$ with signs of milk productivity was less dense. It was, respectively, $r=0.31-0.41$ and $r=0.58-0.63(P<0.05)$. This makes it possible to conclude that the studies conducted in this direction are promising, and assessing calves' immune status for predicting the yield of cow milk. The results obtained by us require further confirmation in a more significant number of animals.
\end{abstract}

Key words: calves, cows, blood, milk yield, correlation.

\section{INTRODUCTION}

Livestock production around the world is developing at an intensive pace. And even in the countries of Western Europe and North America, where small farms are traditionally common, there is an increase in the number of animals on farms and a simultaneous increase in their productivity (Lowder et al. 2016). Let alone Eastern Europe, which is characterized by large dairy complexes of industrial type (llchuk and Konoval 2016).

An increase in the number of farm animals is associated with the complexities of management and veterinary care, and the deterioration of their health (Barkema et al. 2015;

Corresponding author: Ewa Czerniawska-Piątkowska, Department of Ruminant Science, West Pomeranian University of Technology, Szczecin, Klemensa Janickiego 29, 71-270 Szczecin, Poland, e-mail: Ewa.Czerniawska-Piatkowska@zut.edu.pl 
Murray et al. 2015; Wolf et al. 2016; Song et al. 2018). Obviously for this reason, as well as due to over-intensive exploitation, their morbidity and decrease in the productive longevity of dairy cows is occur (Curone et al. 2018; Benvenuti et al. 2018).

This leads to the problem of timely replenishment of the herd by heifers, so growing heifers is an extremely important issue (Imani et al. 2017; Wilson et al. 2017). A great deal of attention is focused on early prediction of the future productivity of calves (McNeel et al. 2017). At the same time, growth and development rates during ontogeny are very often examined, but blood values are evaluated rarely (Soberon et al. 2012; De Paula et al. 2017; Mirzaei et al. 2018).

The calf's organism is closely related to the mother, whose influence both during and after the calving (by means of colostrums immunity) can influence the growth, health and productivity of the future cow (Windeyer et al. 2014; Pardon et al. 2015; Cummins et al. 2017). Initially, colostrums immunity and then the immunobiological status of the calf (humoral and cellular defense factors) largely affect the health of animals and the success of their growth (Nagy et al. 2014; Nagyová et al. 2016). Therefore, their research as predictors of productivity that will be obtained from animals in the future is of scientific and practical interest in the dairy industry.

In the literature available to us, there is little information about the relationship between the indices of humoral and cellular immunity of calves with the future productivity of the cow. These indicators have traditionally been used to characterize the immunobiological reactivity of an organism and the health of calves (Sidel'nikova et al. 2015; Buczinski et al. 2017), and little information is available on their relationship to the dairy cow's productive longevity. Partly, this is due to the difficulties associated with the duration of research, as the cow must complete its productive life. And also many of the experimental animals drop out prematurely from the herd, therefore there is always a small number of experimental groups in such studies. The aim of the study was to evaluate the correlation between the immunobiological parameters of the blood of three-month-old calves which were intensively grown and their dairy productivity in a lifetime. We had a hypothesis that the stability of the calf's organism should influence the future productivity of the cow, including productive longevity.

\section{MATERIAL AND METHODS}

Research was conducted in the private enterprise "Agro-Soyuz" of the Dnipropetrovsk region in the conditions of a high-tech dairy complex equipped with the equipment of BouMatic (USA). The company is a model farm for the breeding of livestock Holstein. The model group of newborn calves was formed in an amount of 30 heads (the animals were selected according to the same live weight, sex and breed). Blood was taken at the age of one, three and six months. All the rules of bioethics dealing with animals were respected (Directive 2010/63/EC and Directive 98/58/EC). The calves were weighed at the age of 3, 6, 9, 12, 15 and 18 months, and also before insemination. Cow's lifelong milk productivity was taken into account in the management system of dairy cattle breeding "Orsek" for indicators of milk yield, yield of fat and protein. Were considered only those cows which had completed at least two lactations. Laboratory studies were conducted in SRC for Biosafety and environmental control of agro-industrial complex Dnipropetrovs'k State Agrarian and Economic 
University (Dnipro) and in the laboratory of clinical biochemistry and immunochemistry National Scientific Center "Institute of Experimental and Clinical Veterinary Medicine" (Kharkiv). The parameters of humoral and cellular defense of the body were determined by the methods described in the work (Chumachenko et al. 2005). Immunoglobulin's contents of $G$ and $M$ class was measured by the method of radial immunodiffusion in the gel (Mancini 1965). Biometric data processing (Plohinskij 1969) was carried out using MS Excel software using built-in statistical functions and Stat Soft STATISTICA ${ }^{\odot} 10$ (McDonald 2009).

\section{RESULTS AND DISCUSSION}

The given data shows (Table 1), that the growth of heifers of Ukrainian Holstein in postnatal ontogeny was satisfactory. It corresponded to the Holstein breed standard, which is adopted in Ukraine (Instruction for estimation of cattle of dairy and dairy-meat breeds, 2004). At the age of $9,12,15$ and 18 months heifers weight exceeded the breed standard by $7.3 \mathrm{~kg}$, $46.1 \mathrm{~kg}, 74.0$ and $94.4 \mathrm{~kg}$. And this is all despite the fact that the heifers weight in 6 months was below the breed standard by $2.9 \%$ that we tend to associate with growing the heifers in conditions of intensive rearing.

Table 1. Indicators of heifers growth of Ukrainian Holstein in ontogenesis, $n=12$

\begin{tabular}{lllll}
\hline \multicolumn{1}{c}{ Index } & Units & $\mathrm{M}$ & $\mathrm{m}$ & $\mathrm{Cv}$ \\
\hline Live weight at birth & $\mathrm{kg}$ & 41.1 & 0.77 & 6.2 \\
\hline Live weight at 3 months & $\mathrm{kg}$ & 93.7 & 2.80 & 9.9 \\
\hline Live weight at 6 months & $\mathrm{kg}$ & 170.0 & 5.26 & 7.6 \\
\hline Live weight at 9 months & $\mathrm{kg}$ & 241.3 & 9.25 & 8.5 \\
\hline Live weight at 12 months & $\mathrm{kg}$ & 334.1 & 9.17 & 7.3 \\
\hline Live weight at 15 months & $\mathrm{kg}$ & 412.0 & 11.60 & 7.1 \\
\hline Live weight at 18 months & $\mathrm{kg}$ & 479.4 & 10.50 & 6.2 \\
\hline Age of insemination & $\mathrm{day}$ & 500.2 & 19.44 & 12.9 \\
\hline Live weight at insemination & $\mathrm{kg}$ & 442.6 & 15.06 & 11.3 \\
\hline
\end{tabular}

$\mathrm{M}$ - the arithmetic mean, $\mathrm{m}$ - the error of the arithmetic mean, $\mathrm{Cv}-$ the coefficient of variability.

Having good growth energy during puberty, the cows that were obtained from these heifers had a high enough milk lifetime yield, milk fat yield and protein. Milk yield had a high variability ( $\mathrm{Cv}=51 \%)$, since from a separate cow, were obtained from 16,293 to $82,121 \mathrm{~kg}$ of milk, which had respectively 2 and 7 complete lactations. In general, animals had a low duration of productive use (Table 2).

Table 2. Indicators of cows milk productivity of Ukrainian Holstein, $n=12$

\begin{tabular}{lccrc}
\hline \multicolumn{1}{c}{ Index } & Units & $\mathrm{M}$ & $\mathrm{m}$ & Cv \\
\hline Lactation period & day & 1555.0 & 194.59 & 41.5 \\
\hline Completed lactation & amount & 3.4 & 0.51 & 49.1 \\
\hline Lifetime yield of milk & $\mathrm{kg}$ & 42947.1 & 6561.01 & 50.6 \\
\hline Lifetime yield of milk fat & $\mathrm{kg}$ & 1254.6 & 203.14 & 53.7 \\
\hline Lifetime protein yield & $\mathrm{kg}$ & 1048.4 & 160.87 & 50.9 \\
\hline
\end{tabular}

Explanations see Table 1. 
We attributed this to their very intensive use in industrial milk production technology. This was confirmed in our previous works and in the reports of other researchers (McConnel et al. 2015; Shahid et al. 2015). Therefore, it is important to find markers that characterize the state of health and are related to the future productivity of cows. Among them, there are blood and immunity values, according to researchers (Nagy et al. 2014; Nagyová et al. 2016). Therefore, as such markers, we chose indicators of resistance of the body and immunoglobulins content in the calf serum (Table 3).

Table 3. Values of body resistance and the immunoglobulins content of classes $G$ and $M$ in the heifers blood at the age of three months, $n=12$

\begin{tabular}{lcccc}
\hline \multicolumn{1}{c}{ Index } & Units & $\mathrm{M}$ & $\mathrm{m}$ & $\mathrm{CV}$ \\
\hline Lysozyme activity of blood serum & $\%$ & 31.0 & 1.78 & 19.0 \\
\hline Bactericidal activity of blood serum & $\%$ & 64.8 & 2.23 & 11.4 \\
\hline Phagocytic activity of neutrophils & $\%$ & 26.6 & 3.1 & 38.7 \\
\hline Immunoglobulins G & $\mathrm{g} \cdot \mathrm{I}^{-1}$ & 12.9 & 0.33 & 8.6 \\
\hline Immunoglobulins M & $\mathrm{g} \cdot \mathrm{I}^{-1}$ & 2.5 & 0.09 & 9.6 \\
\hline
\end{tabular}

Explanations see Table 1.

This age period was chosen because the calves immunological status was fully formed (Batista et al. 2015). And also this is a rather convenient age for early prediction of future dairy productivity and making the appropriate management decisions for calves. In addition, the density of positive correlation between the signs listed below (Table 4-5), in other age periods was lower.

Table 4. Correlation between the state of body resistance of heifers at the age of three months and milk productivity

\begin{tabular}{lcccccc}
\hline \multirow{2}{*}{ Trait } & \multicolumn{2}{c}{$\begin{array}{c}\text { Lysozyme activity of } \\
\text { blood serum }\end{array}$} & \multicolumn{2}{c}{$\begin{array}{c}\text { Bactericidal activity of } \\
\text { blood serum }\end{array}$} & \multicolumn{2}{c}{$\begin{array}{c}\text { Phagocytic activity of } \\
\text { neutrophils }\end{array}$} \\
\cline { 2 - 7 } & $\mathrm{r}$ & $\mathrm{R}^{2}[\%]$ & $\mathrm{r}$ & $\mathrm{R}^{2}[\%]$ & $\mathrm{r}$ & $\mathrm{R}^{2}[\%]$ \\
\hline Lactation period & $0.584^{*}$ & 34.1 & $0.667^{*}$ & 44.5 & 0.177 & 3.4 \\
\hline Completed lactation & $0.636^{*}$ & 40.4 & $0.691^{*}$ & 47.8 & 0.375 & 14.0 \\
\hline Lifetime yield of milk & 0.573 & 32.9 & $0.628^{*}$ & 39.5 & 0.314 & 9.8 \\
\hline Lifetime yield of milk fat & $0.590^{*}$ & 34.7 & $0.626^{*}$ & 39.2 & 0.406 & 16.5 \\
\hline Lifetime protein yield & 0.566 & 32.0 & 0.614 & 37.7 & 0.406 & 16.4 \\
\hline
\end{tabular}

$r$ - the correlation coefficient; $R^{2}-$ the coefficient of determination ${ }^{*} P<0.05$.

Table 5. Correlation between the immunoglobulins content at the age of three months and milk productivity

\begin{tabular}{llllc}
\hline \multirow{2}{*}{ Trait } & \multicolumn{2}{c}{ Immunoglobulins $\mathrm{G}$} & \multicolumn{2}{c}{ Immunoglobulins M } \\
\cline { 2 - 5 } & $\mathrm{r}$ & $\mathrm{R}^{2}[\%]$ & $\mathrm{r}$ & $\mathrm{R}^{2}[\%]$ \\
\hline Lactation period & 0.460 & 21.2 & 0.507 & 25.6 \\
\hline Completed lactation & $0.615^{*}$ & 37.8 & $0.657^{*}$ & 43.1 \\
\hline Lifetime yield of milk & 0.558 & 31.1 & $0.587^{*}$ & 34.4 \\
\hline Lifetime yield of milk fat & $0.585^{*}$ & 34.2 & $0.626^{*}$ & 39.1 \\
\hline Lifetime protein yield & $0.580^{*}$ & 33.6 & $0.618^{*}$ & 38.2 \\
\hline
\end{tabular}

Explanations see Table 4. 
The data given in the Tables (4-5) indicates a reliable positive relationship between the signs of dairy productivity of Ukrainian Holstein (lifetime milk yield, milk fat yield and protein) and their immunobiological status at the age of 3 months. At the same time, the highest correlation was established between the indicators of milk productivity and bactericidal activity of blood serum $(r=0.63-0.69, P<0.05)$.

The relationship between cellular factors of body defense (neutrophils phagocytic activity) and the immunoglobulins content of classes $\mathrm{G}$ and $\mathrm{M}$ was less dense. It was, respectively, $r=0.31-0.41$ and $r=0.58-0.63(P<0.05)$. It is noteworthy that the indicators of productive longevity of Ukrainian Holstein cows were due to the immunobiological status of the calves' organism by $21-47 \%$, proceeding from the immunity's humoral factors.

\section{CONCLUSIONS}

The results of the conducted studies indicate the existence of a positive correlation between the values of nonspecific resistance of the calves' organism and their dairy productivity in the future. A reliable high positive relationship was found between the bactericidal activity of blood serum in heifers at the age of three months and lifelong milk yield, the yield of milk fat and protein. Correlation between these parameters and lysozyme activity of blood serum, the content of immunoglobulins of classes $G$ and $M$ was less dense. At the same time, quite low and unreliable positive relationship was traced between indicators of lifelong productivity and phagocytic activity of blood neutrophils. Thus, the expediency of using immunobiological indicators of calves' blood is shown with the aim of predicting the dairy productivity of cows in the future. However, these results should be considered only as preliminary data, which need to be confirmed on larger number of animals.

\section{REFERENCES}

Barkema H.W., Keyserlingk M.A.G. von, Kastelic J.P., Lam T.J.G.M., Luby C., Roy J.-P., Kelton D.F. 2015. Invited review: Changes in the dairy industry affecting dairy cattle health and welfare. J. Dairy Sci. 98(11), 7426-7445.

Batista C.F., Blagitz M.G., Bertagnon H.G., Gomes R.C., Santos K.R., Della Libera A.M.M.P. 2015. Evolution of phagocytic function in monocytes and neutrophils blood cells of healthy calves. J. Dairy Sci. 98(12), 8882-8888.

Benvenuti M.N., Giuliotti L., Lotti C., Accorsi P.A., Petrulli C.A., Martini A. 2018. Welfare parameters in dairy cows reared in tie-stall and open-stall farming systems: pilot study. J. Hellenic Vet. Med. So. 69(1), 809.

Buczinski S., Gicquel E., Fecteau G., Takwoingi Y., Chigerwe M., Vandeweerd J.M. 2017. Systematic review and meta-analysis of diagnostic accuracy of serum refractometry and brix refractometry for the diagnosis of inadequate transfer of passive immunity in calves. J. Vet. Int. Med. 32(1), 474-483.

Chumachenko V.Yu., Tsvilikhovskyi M.I., Chumachenko V.V., Pavlenko O.I., Makarin A.O., Bereza V.I., Boiko N.I. 2005 Metodolohichna otsinka klinichnykh ta imunolohichnykh doslidzhen u diahnostytsi, likuvanni i profilaktytsi khvorob imunnoi patolohii u tvaryn. Kyiv, Vyd-vo NUBiP Ukrainy. [in Ukrainian] 
Cummins C., Berry D.P., Murphy J.P., Lorenz I., Kennedy E. 2017. The effect of colostrum storage conditions on dairy heifer calf serum immunoglobulin $G$ concentration and preweaning health and growth rate. J. Dairy Sci. 100(1), 525-535.

Curone G., Filipe J., Cremonesi P., Trevisi E., Amadori M., Pollera C., Riva F. 2018. What we have lost: Mastitis resistance in Holstein Friesians and in a local cattle breed. Res. Vet. Sci. 116, 88-98.

De Paula M.R., Oltramari C.E., Silva J.T., Gallo M.P.C., Mourão G.B., Bittar C.M.M. 2017. Intensive liquid feeding of dairy calves with a medium crude protein milk replacer: Effects on performance, rumen, and blood parameters. J. Dairy Sci. 100(6), 4448-4456.

Ilchuk N.M., Konoval I.A. 2016. Povyshenie konkurentosposobnosti produkcii skotovodstva v Ukraine [Increasing the competitiveness of livestock products in Ukraine]. Jekonomika APK 5(259), 51-59. [in Russian]

Imani M., Mirzaei M., Baghbanzadeh-Nobari B., Ghaffari M.H. 2017. Effects of forage provision to dairy calves on growth performance and rumen fermentation: A meta-analysis and metaregression. J. Dairy Sci. 100(2), 1136-1150.

Instruktsiia z bonituvannia velykoi rohatoi khudoby molochnykh i molochnomiasnykh porid. Instruktsiia z vedennia pleminnoho obliku v molochnomu i molochno-miasnomu skotarstvi. 2004. Kyiv, PPNY. [in Ukrainian]

Lowder S.K., Skoet J., Raney T. 2016. the number, size, and distribution of farms, smallholder farms, and family farms worldwide. World Develop. 87, 16-29.

Mancini G. 1965. Immunochemical quantitation of antigens by single radial immunodiffusion. Molecular Immunol. 2(3), 235-244.

McConnel C., Lombard J., Wagner B., Kopral C., Garry F. 2015. Herd factors associated with dairy cow mortality. Animal 9(8), 1397-1403.

McDonald J.H. 2009. Handbook of biological statistics. Baltimore, Sparky House Publishing.

McNeel A.K., Reiter B.C., Weigel D., Osterstock J., Di Croce F.A. 2017. Validation of genomic predictions for wellness traits in US Holstein cows. J. Dairy Sci. 100(11), 9115-9124.

Mirzaei M., Dadkhah N., Baghbanzadeh-Nobari B., Agha-Tehrani A., Eshraghi M., Imani M., Ghaffari M.H. 2018. Effects of preweaning total plane of milk intake and weaning age on intake, growth performance, and blood metabolites of dairy calves. J. Dairy Sci. 101(5), 4212-4220.

Murray C.F., Fick L.J., Pajor E.A., Barkema H.W., Jelinski M.D., Windeyer M.C. 2015. Calf management practices and associations with herd-level morbidity and mortality on beef cow-calf operations. Animal 10(03), 468-477.

Nagy O., Tóthová C., Kováč G. 2014. Age-related changes in the concentrations of serum proteins in calves. J. Appl. Anim. Res. 42(4), 451-458.

Nagyová V., Tóthová C., Nagy O. 2016. The impact of colostrum intake on the serum protein electrophoretic pattern in newborn ruminants. J. Appl. Anim. Res. 45(1), 498-504.

Pardon B., Alliët J., Boone R., Roelandt S., Valgaeren B., Deprez P. 2015. Prediction of respiratory disease and diarrhea in veal calves based on immunoglobulin levels and the serostatus for respiratory pathogens measured at arrival. Prevent. Vet. Med. 120(2), 169-176.

Plohinskij N.A. 1969. Rukovodstvo po biometrii dlja zootehnikov. Moskva, Kolos. [in Russian]

Shahid M.Q., Reneau J.K., Chester-Jones H., Chebel R.C., Endres M.I. 2015. Cow- and herd-level risk factors for on-farm mortality in Midwest US dairy herds. J. Dairy Sci. 98(7), 4401-4413.

Sidel'nikova V.I., Chernitskiy A.E., Zolotarev A.I., Retsky M.I. 2015. Individual reactivity of granulocytic system of newborn calves and its role in pathogenesis of inflammatory diseases of respiratory and gastrointestinal tracts. Sel'skokhozyaistv. Biol. 50(4), 486-494.

Soberon F., Raffrenato E., Everett R.W., Van Amburgh M.E. 2012. Preweaning milk replacer intake and effects on long-term productivity of dairy calves. J. Dairy Sci. 95(2), 783-793.

Song X., Bokkers E.A.M., Tol P.P.J. van der, Groot Koerkamp P.W.G., Mourik S. van. 2018. Automated body weight prediction of dairy cows using 3-dimensional vision. J. Dairy Sci. 101(5), 4448-4459. 
Wilson B.K., Richards C.J., Step D.L., Krehbiel C.R. 2017. Beef species symposium: Best management practices for newly weaned calves for improved health and well-being1. J. Anim. Sci. 95(5), 2170-2182.

Windeyer M.C., Leslie K.E., Godden S.M., Hodgins D.C., Lissemore K.D., LeBlanc S.J. 2014. Factors associated with morbidity, mortality, and growth of dairy heifer calves up to 3 months of age. Prevent. Vet. Med. 113(2), 231-240.

Wolf C.A., Tonsor G.T., McKendree M.G.S., Thomson D.U., Swanson J.C. 2016. Public and farmer perceptions of dairy cattle welfare in the United States. J. Dairy Sci. 99(7), 5892-5903. 
